\title{
A comparative study of the influence of two types of PHEMA stents on the differentiation of ASCs to myocardial cells
}

\author{
SHEN LAO ${ }^{1}$, JING XU $^{2}$, YUNQI LIU ${ }^{3}$, SONGWANG CAI $^{1}$, LIN LIN $^{3}$, \\ JUNHANG ZHANG ${ }^{1}$, DONGMEI CAI ${ }^{3}$ and SHENGLI YIN ${ }^{3}$ \\ ${ }^{1}$ Department of Cardiothoracic Surgery, The Third Affiliated Hospital, Sun Yat-sen University, Guangzhou, \\ Guangdong 510630; ${ }^{2}$ Department of Ultrasonography, The First Affiliated Hospital, \\ Guangdong Pharmaceutical University; ${ }^{3}$ Department of Cardiac Surgery, \\ The First Affiliated Hospital, Sun Yat-sen University, Guangzhou, Guangdong 510080, P.R. China
}

Received January 2, 2016; Accepted February 7, 2017

DOI: $10.3892 / \mathrm{mmr} .2017 .6680$

\begin{abstract}
In the present study, subcutaneous fat was obtained from adult women that had undergone conventional liposuction surgery. A comparative study was performed to investigate the effect of transparent and white poly- $\beta$-hydroxyethyl methacrylate (PHEMA) stents, which have different surface and cross-sectional morphological characteristics, on the differentiation of adipose-derived stem cells (ASCs) into myocardial cells. The cell counting kit- 8 assay revealed that cell growth increased at varying rates among the different treatment groups. The absorbance of the experimental transparent PHEMA treated group increased in a time-dependent manner with the duration of incubation. The highest levels of proliferation were observed in the transparent PHEMA group. In addition, the transparent PHEMA treated group exhibited the strongest cell adhesion ability, which was significantly different to that of the white PHEMA group $(\mathrm{P}<0.01$ and $\mathrm{P}<0.05$ for Matrigel and fibronectin assay, respectively). Comparisons between the two stent materials with the inducer control group revealed statistically significant differences in the rate of ASC differentiation $(\mathrm{P}<0.05)$. The level of differentiation was the greatest in the transparent PHEMA group, and was significantly different to the white PHEMA group $(\mathrm{P}<0.05)$ and the blank control group $(\mathrm{P}<0.01)$. The results suggest that the inducers 5-aza-2-deoxycytidin and laminin, and material microstructure stents effectively promote the proliferation, growth and adhesion of ASCs. However, the transparent material microstructure may be a more suitable candidate for ASC-associated injections. The present study provides further evidence that a PHEMA stent structure, comprised of a high number of matrixes and a
\end{abstract}

Correspondence to: Dr Shengli Yin, Department of Cardiac Surgery, The First Affiliated Hospital, Sun Yat-sen University, 58 Zhongshan 2nd Road, Guangzhou, Guangdong 510080, P.R. China

E-mail: ysheng103@126.com

Key words: adipose-derived stem cells, microporous poly- $\beta$ hydroxyethyl methacrylate, myocardial cells, tissue engineering low water content, induces a high level of ASC differentiation to myocardial cells.

\section{Introduction}

Ischemic cardiomyopathy (ICM) involving damage to cardiac structure and function induced by irreversible myocardial cell necrosis is a leading cause of morbidity and mortality worldwide as a result of modern lifestyle (1). The currently available primary treatments include drug interventions, percutaneous coronary intervention (PCI), coronary artery bypass grafting $(\mathrm{CABG})$ and heart transplantation (2). Although these methods lower the fatality rates and improve the quality of life of patients, a number of limitations and defects still exist. For example, CABG has been observed to lower the rates of mortality and myocardial infarction, however, it increased the incidence of stroke. In addition, the differences in quality-of-life were smaller than expected as many of the patients who were initially treated with PCI required a repeat revascularization procedure (3). However, regenerative medicine is continuously developing, and transplant therapy using muscle tissue has become a primary focus within the field. The aim of this approach is to implant appropriate seed stem cells into specific tissue engineering materials in vitro. Integrated mechanical, chemical and biological signals would then be applied to stimulate and construct functional myocardial tissue. Finally, the tissue would be implanted into the patient to repair or replace the damaged cardiac muscle.

Selecting the appropriate seed cells is the most important step during the construction of myocardial tissues. Adipose-derived mesenchymal stem cells (ASCs) have been successfully isolated from human adipose tissue by Zuk et al (4) using widely available materials. The culture period is long, however, the cells produced exhibit strong proliferation abilities. In addition, this method is ethically approved, and the stem cells have the potential to differentiate into multiple germ layers, which can be induced to differentiate into cardiomyocytes directly $(5,6)$. In addition, ASCs exhibit the same immunosuppressive effects and paracrine signaling abilities as bone mesenchymal stem cells (7-9). 
Stent materials and the culture microenvironment are equally important in myocardial tissue engineering. Previous studies have demonstrated that the spatial microstructure of stent materials has a significant impact on the proliferation and differentiation of seed stem cells $(10,11)$. The ideal stent material for tissue engineering is a natural tissue, and the cultivation environment for cell stent planting should be similar to the microenvironment of human myocardial tissues in order to enhance stem cell adhesion and proliferation, as well as their differentiation into myocardial cells $(6,7)$. Therefore, the concept of using extracellular matrix (ECM) in myocardial tissue engineering has been proposed, and associated studies have gained a great deal of attention (12-14). Consequently, the present study compared the effect of two types of poly- $\beta$-hydroxyethyl methacrylate (PHEMA) stents (transparent and white PHEMA), on ASC proliferation, adhesion and their differentiation into cardiomyocyte-like cells.

\section{Materials and methods}

Reagents. Dulbecco's modified Eagle's medium (DMEM) was purchased from Hyclone; GE Healthcare Life Sciences (Logan, UT, USA); fetal bovine serum (FBS) was purchased from Gibco; Thermo Fisher Scientific, Inc. (Waltham, MA, USA); cell counting kit (CCK)-8 solution was purchased from Yeasen Biotech (Hong Kong) Co., Ltd., (Hong Kong, China); the type I collagen enzyme, decitabine (5-aza-2'-deoxycytidine) and laminin (LN) were purchased from Sigma-Aldrich; Merck KGaA (Darmstadt, Germany); 2-hydroxyethyl methacrylate (HEMA) was purchased from Rohm \& Haas Company (Philadelphia, PA, USA); ethylene glycol dimethacrylate (EGDMA) was purchased from Tokyo Kasei Kogyo Co., Ltd., (Tokyo, Japan); ammonium persulfate (APS) was purchased from Ajax Finechem; Thermo Fisher Scientific, Inc.; N,N,N',N'-tetramethylethylenediamine (TEMED) was purchased from Sigma-Aldrich; Merck KGaA; the GATA binding protein 4 (Gata4; cat. no. GTX113194), NK2 homeobox 5 (Nkx2.5; cat. no. GTX133155), cardiac troponin T (cTnT; cat. no. GTX28295), connexin-43 (Cx43; cat. no. GTX11369), myogenic differentiation (MyoD; cat. no. GTX100885), $\alpha$-smooth muscle actin ( $\alpha$-SMA), desmin (cat. no. GTX103557) and $\beta$-actin (cat. no. GTX110564) antibodies were purchased from GeneTex, Inc. (Irvine, CA, USA); horseradish peroxidase (HRP)-conjugated goat anti-rabbit IgG and HRP-conjugated goat anti-mouse IgG secondary antibodies (heavy and light chain; cat. no. 106003) were purchased from Neobioscience Technology Company (Shenzhen, China).

Preparation of the PHEMA porous hydrogel stent and morphological analysis. As described by Lou et al (15), $1.5 \mathrm{ml}$ of HEMA monomer (Rohm \& Haas Company) was injected into a small cylindrical polystyrene mold with a diameter of $15 \mathrm{~mm}$. The monomer was polymerized at $50^{\circ} \mathrm{C}$ for $20 \mathrm{~h}$, before the mixture was poured into a Soxhlet extractor. Ionized water was used to elute residual monomers and oligomers for $48 \mathrm{~h}$ at room temperature $\left(18-20^{\circ} \mathrm{C}\right)$. The crosslinking agent EGDMA (Tokyo Kasegi Kogyo Co., Ltd.), the APS initiator (Ajax Finechem; Thermo Fisher Scientific, Inc.), TEMED (Sigma-Aldrich; Merck KGaA) and deionized water were added to the two polymer types, which were prepared in a HEMA sponge, to conduct polymerization. To prepare transparent PHEMA, $101.5 \mu \mathrm{l}$ EGDMA, $80 \mu \mathrm{l}$ APS, $40 \mu \mathrm{l}$ TEMED and $6 \mathrm{~g}$ of deionized water were added. For white PHEMA, $36.5 \mu$ l EGDMA, $80 \mu$ l APS, $40 \mu$ l TEMED and $15 \mathrm{~g}$ of deionized water were added. The percentage of water in the transparent PHEMA was 29.9 and $74.8 \%$ in white PHEMA. Morphological analysis was performed on the surface and on cross-sections of the two polymer types using scanning electron microscopy (magnification, $\mathrm{x} 1,000$ ).

Advanced ASC separation and cultivation methodology. A total of 5 female patients (age, 27 \pm 2 years) from The First Affiliated Hospital, Sun Yat-sen University (Guangdong, China) were enrolled in January 2012. Using the syringe negative pressure method as described by Panfilov et al (16), $50 \mathrm{ml}$ human abdominal subcutaneous suction fat fluid was collected from the excess tissues excised during plastic and reconstructive surgery (excessive inflation fluid, auxiliary ultrasonic emulsification or resonance technology were not required). A total of $50 \mathrm{ml}$ phosphate-buffered saline (PBS) was added, followed by thorough mixing and centrifugation at $1,200 \mathrm{xg}$ for $10 \mathrm{~min}$ at $37^{\circ} \mathrm{C}$. The supernatant was removed and transferred into a fresh centrifuge tube $(50 \mathrm{ml})$ with 5 -fold the volume of Collagenase I $(0.075 \%$; concentration of working liquid; Sigma; Merck $\mathrm{KGaA}$ ). The adipose tissue was then cut into small pieces. The tube was subsequently sealed at $37^{\circ} \mathrm{C}$ and mixed at $200 \mathrm{x} \mathrm{g}$ for $30 \mathrm{~min}$ at $37^{\circ} \mathrm{C}$. Digestion was terminated by adding the same volume of DMEM containing 10\% FBS and the solution was centrifuged at $1,200 \mathrm{xg}$ for $10 \mathrm{~min}$ at $37^{\circ} \mathrm{C}$. The supernatant was removed for incubation at room temperature for $5 \mathrm{~min}$, followed by centrifugation $1,200 \mathrm{xg}$ for $5 \mathrm{~min}$ at $37^{\circ} \mathrm{C}$. The supernatant was removed and 10X volumes of medium was added. A nylon cell strainer (Corning Life Sciences, Corning, NY, USA) with a pore diameter of $100 \mathrm{~mm}$ was used to filter the tissue block. Cells were incubated in $10-\mathrm{cm}$ culture dishes (inoculation density of $30-50 \%$ ) at $37^{\circ} \mathrm{C}$ and $95 \%$ relative humidity in culture medium (DMEM containing 10\% FBS) to a final volume of $10 \mathrm{ml}$. The medium was refreshed following $24 \mathrm{~h}$, then once every 2.5 days. Cells were passaged when the cell density reached $80-90 \%$. When the cell density of the passage (P) 1 generation reached $80-90 \%$, cells were cryopreserved for induction of differentiation. P2 generation cells were used immediately for the following experiments. All procedures were conformed to the principles outlined in The Declaration of Helsinki. The study protocol was approved by the Human Ethics Committee of The First Affiliated Hospital, Sun Yat-sen University (Guangzhou, China). Written informed consent was obtained for the collection and utilization of tissue samples from all subjects included in the present study.

Cell culture. Human $\mathrm{LN}(1.2 \mathrm{mg} / \mathrm{ml})$ and decitabine $(10 \mathrm{mmol} / \mathrm{ml})$ were added to the pores of the white and transparent PHEMA to induce differentiation of the ASCs into myocardial cells. Following incubation for $2 \mathrm{~h}$ at $37^{\circ} \mathrm{C}$, PBS was used to wash the PHEMA stents. Stent materials were not added to the remaining two pores. To each hole, $5 \times 10^{4}$ ASCs were applied. DMEM ( $\left.2 \mathrm{ml}\right)$ containing $10 \%$ FBS were added to the blank control pores. For the inducer group, $\operatorname{DMEM}(2 \mathrm{ml})$ containing $10 \mu \mathrm{mol} / \mathrm{ml}$ 5-Aza-2'-deoxycytidine and LN $(1.2 \mu \mathrm{g} / \mathrm{ml})+10 \%$ FBS was added the following day and incubated for $24 \mathrm{~h}$ at $37^{\circ} \mathrm{C}$ with $90 \%$ humidity. For the 
stent+inducer group, DMEM $(2 \mathrm{ml})$ containing $10 \mu \mathrm{mol} / \mathrm{ml}$ 5-Aza-2'-deoxycytidine and LN $(1.2 \mu \mathrm{g} / \mathrm{ml})$ on white PHEMA or transparent PHEMA $+10 \%$ FBS was added. The concentration of LN and 5-Aza-2'-deoxycytidine added to the cells was described by van Dijk et al (17).

Cell proliferation analysis. Digestive enzymes were added into the 4 sample holes. A total of $100 \mu 1$ cell solution $(\sim 3,000$ cells $)$ was added to each hole. Following 24 h, $10 \mu \mathrm{l} \mathrm{CCK-8} \mathrm{solution}$ and $90 \mathrm{ml}$ complete medium were applied. The cells were then incubated for a further $1 \mathrm{~h}$, and the absorbance was measured at $450 \mathrm{~nm}$.

Test for cell adhesion. To test cell adhesion capabilities, $10 \mathrm{~g} / 1$ bovine serum albumin (BSA), $50 \mathrm{mg} / 1$ Matrigel (dilution, 1:8) or $10 \mathrm{mg} / \mathrm{l}$ fibronectin (FN) were added into 96 -well plates, with $50 \mu \mathrm{l}$ in each well. The cells were incubated at $4^{\circ} \mathrm{C}$ with $90 \%$ humidity overnight. BSA was used as the control base. Excess liquid in the culture plate was removed. A total of $50 \mu \mathrm{l}$ serum-free culture medium containing $10 \mathrm{~g} / 1 \mathrm{BSA}$ was added into each well and incubated in a water bath at $37^{\circ} \mathrm{C}$ for $30 \mathrm{~min}$. A total of $4 \mathrm{ml}$ of $0.25 \%$ digestive enzymes were added into the 4 sample holes and the cell density was adjusted to $1 \times 10^{5}$ cells $/ \mathrm{ml}$. The cell suspension $(100 \mu \mathrm{l})$ was inoculated in the coated 96-well plate; 3 parallel samples were used for each group. A total of $10 \mathrm{~g} / 1$ medium containing BSA was used for control culture at $37^{\circ} \mathrm{C}$ for $1 \mathrm{~h}$ and the nutrient solution was removed. The CCK- 8 method was used to determine the absorbance at $450 \mathrm{~nm}$. With the absorbance value of adherent cells in the BSA group as the reference, the adherence rates of the Matrigel group and FN group were calculated. Adhesion rate was calculated using the following formula: Adhesion rate $(\%)=\left[\left(\mathrm{OD}_{\text {Matrigel group }}\right.\right.$ or $\left.\left.\mathrm{OD}_{\mathrm{FN} \text { group }} / \mathrm{OD}_{\mathrm{BSA} \text { group }}\right)-1\right] \times 100 \%$.

Western blot analysis to determine the direction of ASC differentiation. ASCs from the 4 sample groups were cultured for 2 weeks at $37^{\circ} \mathrm{C}$ with $90 \%$ humidity. The cells were lysed in lysis buffer [150 mM NaCl, $50 \mathrm{mM}$ Tris- $\mathrm{HCl}(\mathrm{pH} 8.0), 0.1 \%$ SDS, $1 \%$ Triton X-100] containing protease and phosphatase inhibitors (Roche Diagnostics, Basel, Switzerland). Cell lysate protein content was determined using a bicinchoninic acid protein assay kit (Sigma-Aldrich; Merck KGaA). An equal amount of whole cell extracted protein $(10 \mu \mathrm{g})$ was subjected to $12 \%$ SDS-PAGE gel, transferred to PVDF membranes and blocked by non-fat milk in an incubator $\left(26^{\circ} \mathrm{C}, 40 \mathrm{x} \mathrm{g}, 2\right.$ to $\left.4 \mathrm{~h}\right)$. The blocking mixture was then discarded, and a hybrid solution containing primary antibodies (GATA4, Nkx2.5, cTnT, desmin, Cx43, MyoD, $\alpha$-SMA) was added and incubated at $4^{\circ} \mathrm{C}$ overnight. A secondary antibody hybrid solution $(1: 10,000)$ was added the following day, and membranes were incubated at $26^{\circ} \mathrm{C}$ for $1 \mathrm{~h}(40 \mathrm{x} \mathrm{g})$. An electrochemiluminescence kit (Thermo Fisher Scientific, Inc.) and Kodak gel imaging system 2200 (Kodak, Rochester, NY, USA) were used to collect and analyze images.

Statistical analysis. SPSS software (version, 13.0; SPSS, Inc., Chicago, IL, USA) was used for data processing. Data are presented as the mean \pm standard deviation. Student's t-test was used for comparisons between groups, and a one-way analysis of variance with the Bonferroni post hoc test were used to
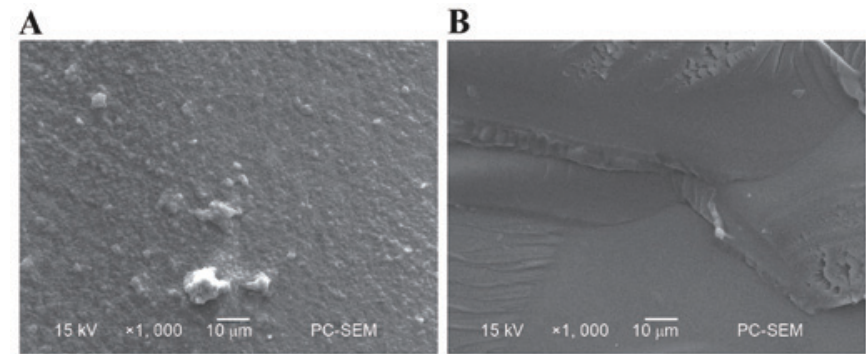

Figure 1. Comparative electron microscope images of the surface morphology between white and transparent PHEMA polymers. (A) White PHEMA polymers (Monomers, 25.2\%; Water, 74.8\%) displayed an uneven surface, while (B) transparent PHEMA polymers (Monomers, 70.1\%; Water, 29.9\%) displayed an even surface (magnification, x1,000). PHEMA, poly- $\beta$-hydroxyethyl methacrylate; PC-SEM, personal computer-scanning electron microscopy.

compare differences among $>3$ groups. $\mathrm{P}<0.05$ and $\mathrm{P}<0.01$ were considered to indicate statistically significant differences.

\section{Results}

Morphological analysis of the PHEMA polymer. The two types of polymers exhibited different surface and cross-sectional morphological characteristics. Differences in pore structure between white and transparent PHEMA polymers are shown in Figs. 1 and 2. The white PHEMA is a milky white polymer with noticeable porous structures. By contrast, the transparent PHEMA is a little translucent and is similar to homogeneous, non-porous hydrogels.

Cell proliferation analysis. Cell proliferation increased to varying extents among all experimental groups, as determined using the CCK-8 assay (Fig. 3). The absorbance of each experimental group increased in a time-dependent manner (Fig. 3). When compared with the control group, the white and transparent stent treated groups demonstrated significantly increased proliferation rates at 48, 72 and $96 \mathrm{~h}$ $(\mathrm{P}<0.05$ and $\mathrm{P}<0.01$; Fig. 3$)$. The transparent PHEMA treated group exhibited higher rates of proliferation when compared with the white PHEMA treated group at 72 and $96 \mathrm{~h}(\mathrm{P}<0.05)$. Therefore, the highest proliferation rate was observed in the transparent PHEMA polymer group at $96 \mathrm{~h}$. The results demonstrated that, under the identical culture conditions, inducers and material microstructures effectively promote the proliferation and growth of ASCs. In addition, the transparent PHEMA polymer microstructure demonstrated the greatest proliferation promotion ability.

Cell adhesion analysis. Cells cultured on Matrigel and FN-coated surfaces demonstrated marked differences in adherence capabilities (Table I). The transparent material group demonstrated the greatest cell adhesion ability, which was significantly greater when compared with the white material group $(\mathrm{P}<0.01$; Table $\mathrm{I})$. The results demonstrated that the inducers and material microstructures effectively promoted the adhesion of ASCs, when compared with the controls. In addition, the microstructure composed of transparent material may present the most suitable candidate for vaccinations of ASCs. 

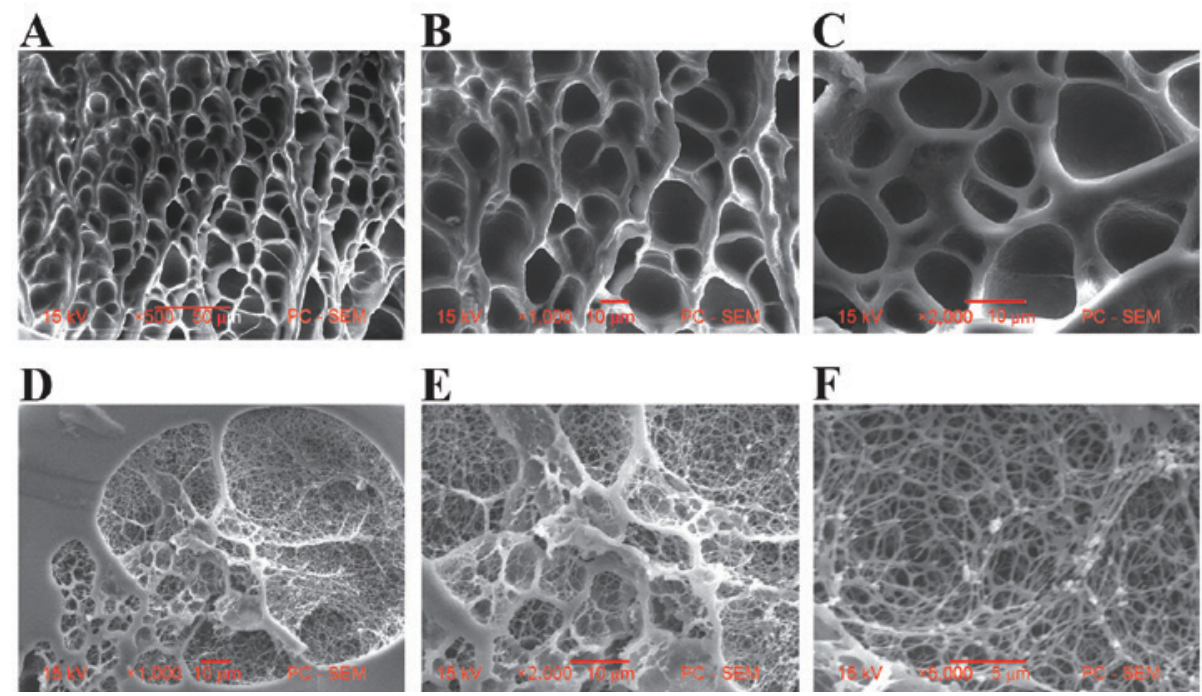

Figure 2. Comparative electron microscope images of the cross-sectional morphologies of white and transparent PHEMA polymers. Images of the porous network structure of white PHEMA polymer samples (Monomers, 25.2\%; Water, 74.8\%) at (A) x500, (B) x1,000 and (C) x2,000 magnifications. The porous network structure containing nanofibers of transparent PHEMA polymer samples (Monomers, 70.1\%; Water, 29.9\%) at (D) x1,000, (E) x2,000, (F) x5,000 magnifications. PHEMA, poly- $\beta$-hydroxyethyl methacrylate; PC-SEM, personal computer-scanning electron microscopy.

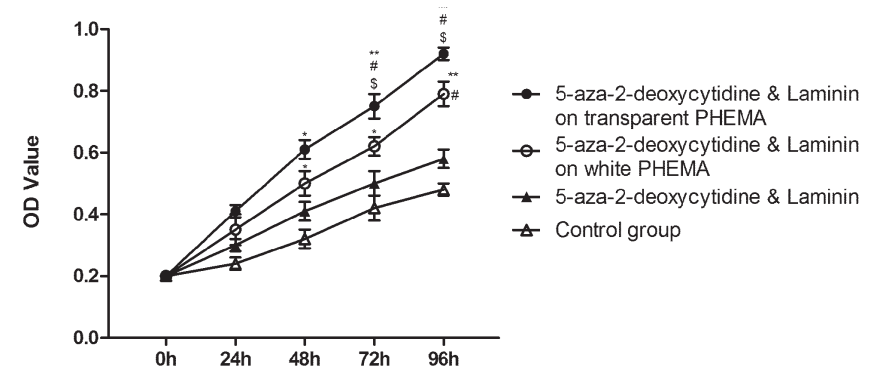

Figure 3. Cell proliferation at different time-points across the 4 groups. Cell proliferation was determined using the cell counting kit- 8 , and is represented by the OD values at $0,24,48,72$ and $96 \mathrm{~h}$, respectively. ${ }^{*} \mathrm{P}<0.05$ and ${ }^{* * *} \mathrm{P}<0.01$ vs. the control group at each time-point; ${ }^{~} \mathrm{P}<0.05$ vs. 5 -aza-2'-deoxycytidine and laminin group; ${ }^{\$} \mathrm{P}<0.05$ vs. white PHEMA group. PHEMA, poly- $\beta$-hydroxyethyl methacrylate; OD, optical density.

Western blot analysis to determine the direction of differentiation of the ASCs. Western blotting was used for the semi-quantitative detection of specific proteins expressed in myocardial stem cells and myocardial cells. Fig. 4 demonstrates that differentiated ASCs expressed the myocardial proteins cTnT, Cx43, desmin, GATA-4 and Nkx-2.5. The results demonstrated that a limited number of ASCs in the blank control group, which were treated without inducers and stent materials, appeared to have differentiated into myocardial stem cells and myocardial cells (Fig. 4). When compared with the blank control group, a statistically significant increase in the expression of myocardial-specific proteins in the inducer-treated control group was observed ( $\mathrm{P}<0.05$; Fig. 4). In addition, when compared to the inducer-treated control group, a statistically significant difference in the rate of differentiation between the two stent material structures under the same experimental conditions was observed ( $\mathrm{P}<0.05$; Fig. 4). The results suggest that the PHEMA stent structure effectively promoted ASCs to differentiate into myocardial cells. Compared with the other groups, the differentiation rate was highest in the transparent PHEMA group (Mon $70.1 \%$, Wat
29.9\%), and was significantly different to the white PHEMA group (Mon 25.2\%, Wat 74.8\%; $\mathrm{P}<0.05$ ) and the blank control group $(\mathrm{P}<0.01 ;$ Fig. 4$)$. The percentage increase in the expression of specific myocardial proteins relative to the controls were as follows: GATA-4, 5.23\%; Nkx-2.5, 5.66\%; cTnT, 36.35\%; desmin, $42.57 \%$; and $\mathrm{Cx} 43,5.78 \%$. The percentage increase in the expression of the myocyte-specific protein, MyoD and the smooth muscle-specific protein, $\alpha$-SMA were 1.03 and $1.07 \%$, respectively, relative to the controls. These results suggest that PHEMA stent structures with a high number of matrixes and a low water content may promote the differentiation of ASCs to myocardial cells.

\section{Discussion}

The development and application of myocardial tissue engineering may provide a novel approach for the clinical treatment of ICM; however, there are currently limitations with regard to the low survival rate of stem cells and the low differentiation rate of cardiomyocyte-like cells following transplantation of seed stem cells $(18,19)$. ASCs are known to be one of the most appropriate type of seed cells for myocardial tissue engineering (20). In order to identify appropriate seed cells, the focus of myocardial tissue engineering research has altered to focus on the construction of a bionic model of myocardial ECM $(21,22)$. This primarily uses technology to integrate stent materials and biologically active substances, as well as stimulate mechanical or chemical signals to create a suitable environment for the survival of stem cells and the differentiation of myocardial cells (23). HEMA is an artificial polymer material used widely in the field of clinical medicine (24). It demonstrates effective biocompatibility, degradability, and resistance to high temperature, acid and alkali hydrolysis. In addition, HEMA possesses a certain level of mechanical strength, elasticity and plasticity $(22,25-28)$. Furthermore, the hydrogel form, comprised of the hydrophilic polymer, serves an important role in clinical applications including tissue 
Table I. Adhesion rate of adipose stem cells following different treatments.

Adhesion rate (\%)

Treatment group

Matrigel

$28.06 \pm 0.35$

$36.17 \pm 1.50^{\mathrm{a}}$

$58.39 \pm 2.26^{\mathrm{a}}$

$72.88 \pm 1.64^{\mathrm{a}, \mathrm{b}}$
FN

$33.74 \pm 1.24$

$48.36 \pm 1.35^{\mathrm{c}}$

$65.99 \pm 2.30^{\mathrm{c}}$

$78.95 \pm 1.53^{\mathrm{c}, \mathrm{d}}$

5-aza-4-deoxycytidin \& LN on transparent PHEMA

Adhesion rate was calculated using the following formula: Adhesion rate $(\%)=\left[\left(\mathrm{OD}_{\text {Matrigel group }}\right.\right.$ or $\left.\left.\mathrm{OD}_{\mathrm{FN} \text { group }} / \mathrm{OD}_{\mathrm{BSA} \text { group }}\right)-1\right] \times 100 \%$. ${ }^{\mathrm{a}} \mathrm{P}<0.01$ vs. Control group of cells coated with Matrigel; ${ }^{\mathrm{b}} \mathrm{P}<0.01$ transparent PHEMA group vs. white PHEMA group of cells coated with Matrigel; ${ }^{\mathrm{c}} \mathrm{P}<0.01$ vs. Control group of cells coated with $\mathrm{FN}$; ${ }^{\mathrm{d}} \mathrm{P}<0.05$ transparent PHEMA group vs. white PHEMA group of cells coated with FN. FN, fibronectin; BSA, bovine serum albumin; PHEMA, poly- $\beta$-hydroxyethyl methacrylate; LN, laminin; OD, optical density.

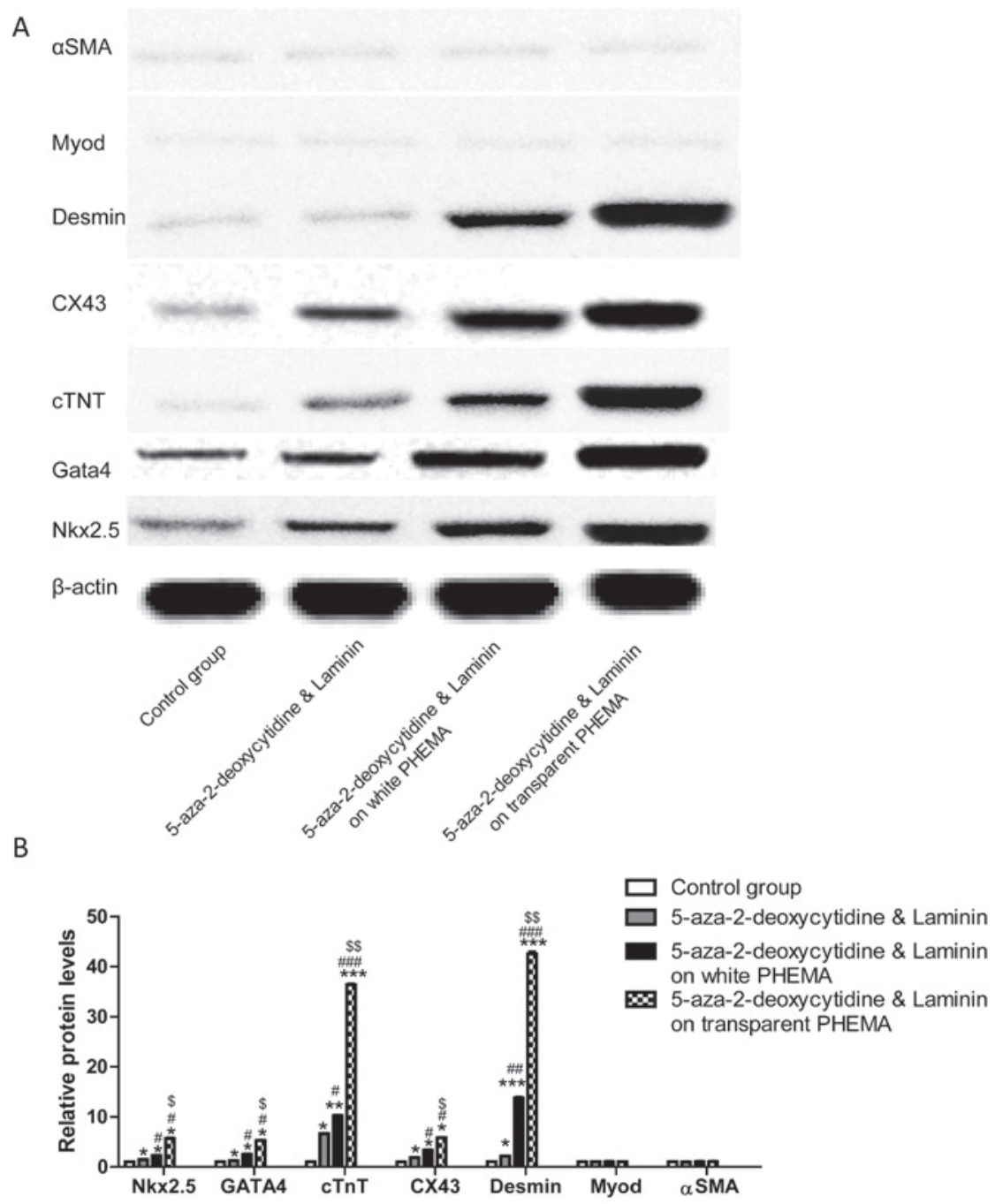

Figure 4. Level of cardiomyocyte-like cell differentiation across the 4 groups. (A) Western blotting analysis of protein expression levels and (B) quantification of the results. The percentage increase in the protein expression levels of differentiation markers relative to control in the adipose-derived stem cells in the transparent group were as follows: GATA-4, 5.23\%; Nkx-2.5, 5.66\%; cTnT, 36.35\%; desmin, 42.57\%; Cx43, 5.78\%. There were no differences observed in the expression of MyoD and $\alpha$-SMA among groups. ${ }^{*} \mathrm{P}<0.05,{ }^{* *} \mathrm{P}<0.01$ and ${ }^{* * *} \mathrm{P}<0.001$ vs. control group; ${ }^{*} \mathrm{P}<0.05,{ }^{\# \#} \mathrm{P}<0.01$ and ${ }^{\# \# \#} \mathrm{P}<0.001$ vs. 5 -aza-2'-deoxycytidine and laminin group; ${ }^{\$} \mathrm{P}<0.05$ and ${ }^{\$ \mathrm{~S}} \mathrm{P}<0.01$ vs. white PHEMA group. Gata4, GATA binding protein 4; Nkx2.5, NK2 homeobox 5; cTnT, cardiac troponin T; Cx43, connexin-43; MyoD, myogenic differentiation; $\alpha$-SMA, $\alpha$-smooth muscle actin; PHEMA, poly- $\beta$-hydroxyethyl methacrylate.

regeneration, heart transplantation and skin grafts $(22,29-31)$. Its three-dimensional rubber structure and high-level of water retention are very similar to that observed in human tissues. The present study used HEMA substrates to form PHEMA 
hydrogel stents. On the one hand, the hydroxyl and carboxyl groups increase the hydrophilic properties of the polymer, however, the hydrophobic methyl groups and the main stem maintain the hydrolytic stability of the polymer and support a certain degree of mechanical strength in the matrix $(32,33)$. In addition, the PHEMA hydrogel form possesses an ideal porous structure. The characteristics of the induction of photopolymerization to phase-separation may be generated by a one-step polymerization reaction.

Previous studies have demonstrated that 5-azathioprine (5-Aza) promotes the differentiation of ASCs to cardiomyocyte-like cells during cultivation $(34,35)$. Planat-Bénard et al (6) and Rangappa et al (36) successfully induced ASC differentiation into active myocardial cells using 5-Aza. Decitabine is an analogue of 2'-deoxycytidine, and demonstrates a 30-fold higher level of inhibitory activity on DNA methylation when compared with 5-Aza $(37,38)$. Previous studies have indicated that two natural ECM components, $\mathrm{LN}$ and $\mathrm{FN}$, serve an important role in the growth and differentiation of ectomesenchymal stem cells in vitro (39-41). $\mathrm{LN}$ and $\mathrm{FN}$ are highly expressed in the normal myocardium following myocardial infarction (42). Van Dijk et al (17) confirmed that FN enhanced the cell adhesion rate of ASCs, while LN improved the differentiation rate of ASCs to cardiomyocyte-like cells. Notably, the data demonstrated that under the co-induction of decitabine and $\mathrm{LN}$, the differentiation rate of ASCs to myocardial cells was as high as $61 \%$. A previous study has revealed that stem cell proliferation decreases following exposure to the inducer 5-Aza (43). The present study utilized a novel type of decitabine and LN to induce and effectively promote the proliferation of ASCs.

The specific myocardial transcription factors, $\mathrm{Nkx} 2.5$ and GATA-4, serve an important role in the early embryonic development of the heart (44). Bai et al (35) and Gassanov et al (45) revealed that $\mathrm{Nkx} 2.5$ induces the transcription of a series of genes in a downstream signaling pathway, by combining the zinc finger structure at the end of GATA-4c, thereby inducing the expression of a large number of myocardial transcription factors $(46,47)$. Therefore, $\mathrm{Nkx} 2.5$ is able to control the original myocardial tube formation and cyclization, as well as myocardial cell differentiation. In addition, the expression of $\mathrm{Nkx} 2.5$ is one of the earliest characteristics of the differentiation of cardiac precursor cells. In the present study, ASCs may have differentiated into cardiomyocyte-like cells following induction, as an overexpression of desmin, cTnT, Cx43, Nkx 2.5 and GATA4, which are markers of cardiomyocyte-like cells, was observed. The blank control group exhibited increased transcription factor and protein expression of $\mathrm{Nkx} 2.5$ and GATA4, demonstrating that free differentiation of ASCs to cardiomyocyte-like cells had occurred without induction. When compared with the blank control group, the level of differentiation in the inducer control group was significantly different, suggesting that the inducer effectively promotes ASC differentiation into cardiomyocyte-like cells. Positive expression of the transcription factors, Nkx2.5 and GATA-4, in the PHEMA groups were higher than that observed in the control group. The results indicated that under the same experimental conditions plus exposure to inducers and chemical factors produced via ASC paracrine signaling mechanisms, the PHEMA stent microstructure promotes the differentiation of ASCs into cardiomyocyte-like cells, and the expression of cardiac differentiation-associated transcription factors. The protein expression levels of cardiac transcription factors were highest in the transparent PHEMA group (Mon $70.1 \%$, Wat $29.9 \%$ ). In addition, the expression levels of the specific myocardial proteins, cTnT, desmin and Cx43 were highest in the transparent PHEMA group, and the expression levels of the specific proteins MyoD and $\alpha$-SMA in myocardial stem cells were lower, suggesting that it may be easier to produce the cardiomyocyte-like phenotype in the transparent PHEMA microstructure. Although the western botting data was not consistent with the high differentiation rate observed by van Dijk et al (17), it was higher than the positive rate observed by Gaustad et al (48).

Cx43 is one of the most important proteins present in the gap junction channels located between mammalian ventricular muscle cells (49). It serves an important role in cardiac development, normal cardiac electrical activity, heart diastolic movement and the differentiation of stem cells to myocardial cells (50). In addition, Cx43 has been observed to be a functional marker of stem cell differentiation to cardiomyocyte-like cells (51). Shulz and Heusch (52) noted that the positive and negative expression of $\mathrm{Cx} 43$ greatly influenced the pathophysiological processes associated with ischemic heart disease and atherosclerosis. Thomas et al (53) demonstrated that when the content of $\mathrm{Cx} 43$ was reduced by $50 \%$, ventricular conduction velocity was subsequently reduced by $38 \%$, which induces intraventricular blocks and leads to arrhythmia and sudden death. This demonstrated that the microstructure of transparent PHEMA may be advantageous to the formation of $\mathrm{Cx} 43$ between cardiomyocyte-like cells and further formation of electrical coupling. However, the present study failed to observe the synchronous pulse of cardiomyocyte-like cells under the microscope. If regular mechanical traction and electrical stimulation that simulate diastole are used to increase ASC mechanical signaling, it is possible that the differentiation rate of cardiomyocyte-like cells may be greatly improved.

The present study only investigated two forms of PHEMA stents. The most suitable proportion of matrix-to-water in the PHEMA stent necessary for the differentiation of cardiomyocyte-like cells requires further investigation, and will be explored in future experiments.

In conclusion, inducers and material stent microstructures effectively promote the proliferation, growth and adhesion of ASCs. In addition, the transparent material microstructure was revealed to be a more suitable candidate for ASC vaccinations. The experiments provide additional evidence to suggest that in PHEMA stents, a structure with a high number of matrixes and a low water content, increases the rate of ASC differentiation to myocardial cells.

\section{References}

1. LaPar DJ, Kron IL and Yang Z: Stem cell therapy for ischemic heart disease: Where are we? Curr Opin Organ Transplant 14: 79-84, 2009.

2. Chang TI, Shilane D, Kazi DS, Montez-Rath ME, Hlatky MA and Winkelmayer WC: Multivessel coronary artery bypass grafting versus percutaneous coronary intervention in ESRD. J Am Soc Nephrol 23: 2042-2049, 2012. 
3. Abdallah MS, Wang K, Magnuson EA, Spertus JA, Farkouh ME, Fuster V and Cohen DJ; FREEDOM Trial Investigators: Quality of life after PCI vs CABG among patients with diabetes and multivessel coronary artery disease: A randomized clinical trial JAMA 310: 1581-1590, 2013

4. Zuk PA, Zhu M, Mizuno H, Huang J, Futrell JW, Katz AJ, Benhaim P, Lorenz HP and Hedrick MH: Multilineage cells from human adipose tissue: Implications for cell-based therapies. Tissue Eng 7: 211-228, 2001.

5. Miyahara Y, Nagaya N, Kataoka M, Yanagawa B, Tanaka K, Hao H, Ishino K, Ishida H, Shimizu T, Kangawa K, et al: Monolayered mesenchymal stem cells repair scarred myocardium after myocardial infarction. Nat Med 12: 459-465, 2006.

6. Planat-Bénard V, Menard C, André M, Puceat M, Perez A, Garcia-Verdugo JM, Pénicaud L and Casteilla L: Spontaneous cardiomyocyte differentiation from adipose tissue stroma cells. Circ Res 94: 223-229, 2004.

7. McIntosh K, Zvonic S, Garrett S, Mitchell JB, Floyd ZE Hammill L, Kloster A, Di Halvorsen Y, Ting JP, Storms RW, et al The immunogenicity of human adipose-derived cells: Temporal changes in vitro. Stem Cells 24: 1246-1253, 2006.

8. Puissant B, Barreau C, Bourin P, Clavel C, Corre J, Bousquet C, Taureau C, Cousin B, Abbal M, Laharrague $\mathrm{P}$, et al: Immunomodulatory effect of human adipose tissue-derived adult stem cells: Comparison with bone marrow mesenchymal stem cells. Br J Haematol 129: 118-129, 2005.

9. Laflamme MA and Murry CE: Heart regeneration. Nature 473 326-335, 2011

10. Singh D, Nayak V and Kumar A: Proliferation of myoblast skeletal cells on three-dimensional supermacroporous cryogels. Int J Biol Sci 6: 371-381, 2010

11. Jin J, Jeong SI, Shin YM, Lim KS, Shin HS, Lee YM, Koh HC and Kim KS: Transplantation of mesenchymal stem cells within a poly(lactide-co-epsilon-caprolactone) scaffold improves cardiac function in a rat myocardial infarction model. Eur $\mathbf{J}$ Heart Fail 11: 147-153, 2009.

12. Akhyari P, Kamiya H, Haverich A, Karck M and Lichtenberg A: Myocardial tissue engineering: The extracellular matrix. Eur J Cardiothorac Surg 34: 229-241, 2008.

13. Vunjak Novakovic G, Eschenhagen $T$ and Mummery $C$ Myocardial tissue engineering: In vitro models. Cold Spring Harb Perspect Med 4: pii: a014076, 2014.

14. Kim Y, Ko H, Kwon IK and Shin K: Extracellular matrix revisited: Roles in tissue engineering. Int Neurourol J 20 (Suppl 1): S23-S29, 2016.

15. Lou X, Munro S and Wang S: Drug release characteristics of phase separation pHEMA sponge materials. Biomaterials 25: 5071-5080, 2004.

16. Panfilov IA, de Jong R, Takashima S and Duckers HJ: Clinical study using adipose-derived mesenchymal-like stem cells in acute myocardial infarction and heart failure. Methods Mol Biol 1036: 207-212, 2013

17. van Dijk A, Niessen HW, Ursem W, Twisk JW, Visser FC and van Milligen FJ: Accumulation of fibronectin in the heart after myocardial infarction: A putative stimulator of adhesion and proliferation of adipose-derived stem cells. Cell Tissue Res 332: 289-298, 2008

18. Tandon N, Cannizzaro C, Chao PH, Maidhof R, Marsano A, Au HT, Radisic M and Vunjak-Novakovic G: Electrical stimulation systems for cardiac tissue engineering. Nat Protoc 4: 155-173, 2009.

19. Zimmermann WH: Remuscularizing failing hearts with tissue engineered myocardium. Antioxid Redox Signal 11: 2011-2023, 2009.

20. Dai R, Wang Z, Samanipour R, Koo KI and Kim K Adipose-derived stem cells for tissue engineering and regenerative medicine applications. Stem Cells Int 2016: 6737345, 2016.

21. Harrison BS and Atala A: Carbon nanotube applications for tissue engineering. Biomaterials 28: 344-353, 2007.

22. Horák D, Hlídková $H$, Hradil J, Lapčíková $M$ and Šlouf $M$ Superporous poly(2-hydroxyethyl methacrylate) based scaffolds: Preparation and characterization. Polymer 49: 2046-2054, 2008

23. Lutolf MP and Hubbell JA: Synthetic biomaterials as instructive extracellular microenvironments for morphogenesis in tissue engineering. Nat Biotechnol 23: 47-55, 2005

24. Vijayasekaran S, Hicks CR, Chirila TV, Fitton JH, Clayton AB, Lou X, Platten S, Crawford GJ and Constable IJ: Histologic evaluation during healing of hydrogel core-and-skirt keratoprostheses in the rabbit eye. Cornea 16: 352-359, 1997.
25. Atzet S, Curtin S, Trinh P, Bryant S and Ratner B: Degradable poly(2-hydroxyethyl methacrylate)-co-polycaprolactone hydrogels for tissue engineering scaffolds. Biomacromolecules 9 : 3370-3377, 2008

26. Kopeček J: Hydrogels from soft contact lenses and implants to self-assembled nanomaterials. J Polym Sci A Polym Chem 47: 5929-5946, 2009

27. Chirila TV: An overview of the development of artificial corneas with porous skirts and the use of PHEMA for such an application. Biomaterials 22: 3311-3317, 2001.

28. Castner DG and Ratner BD: Biomedical surface science: Foundations to frontiers. Surface Sci 500: 28-60, 2002.

29. Lee KY and Mooney DJ: Hydrogels for tissue engineering. Chem Rev 101: 1869-1879, 2001

30. Refojo MF: Hydrophobic interaction in poly(2-hydroxyethyl methacrylate) homogeneous hydrogel. J Polym Sci A1 5: 3103-3113, 1967.

31. Rosiak JM and Yoshii F: Hydrogels and their medical applications. Nuclear Instruments Methods Physics Res Section B: Beam Interactions Materials Atoms 151: 56-64, 1999.

32. Poncin-Epaillard F, Vrlinic T, Debarnot D, Mozetic M, Coudreuse A, Legeay G, El Moualij B and Zorzi W: Surface treatment of polymeric materials controlling the adhesion of biomolecules. J Funct Biomater 3: 528-543, 2012.

33. Thevenot P, Hu W and Tang L: Surface chemistry influence implant biocompatibility. Curr Top Med Chem 8: 270-280, 2008.

34. Schäffler A and Büchler C: Concise review: Adipose tissue-derived stromal cells-basic and clinical implications for novel cell-based therapies. Stem Cells 25: 818-827, 2007.

35. Bai X, Pinkernell K, Song YH, Nabzdyk C, Reiser J and Alt E: Genetically selected stem cells from human adipose tissue express cardiac markers. Biochem Biophys Res Commun 353: 665-671, 2007.

36. Rangappa S, Fen C, Lee EH, Bongso A and Sim EK: Transformation of adult mesenchymal stem cells isolated from the fatty tissue into cardiomyocytes. Ann Thorac Surg 75: 775-779, 2003

37. Zhang DZ, Gai LY, Liu HW, Jin QH, Huang JH and Zhu XY: Transplantation of autologous adipose-derived stem cells ameliorates cardiac function in rabbits with myocardial infarction. Chin Med J (Engl) 120: 300-307, 2007.

38. Burlacu A: Can 5-azacytidine convert the adult stem cells into cardiomyocytes? A brief overview. Arch Physiol Biochem 112: 260-264, 2006

39. Christman KL, Fok HH, Sievers RE, Fang Q and Lee RJ: Fibrin glue alone and skeletal myoblasts in a fibrin scaffold preserve cardiac function after myocardial infarction. Tissue Eng 10: 403-409, 2004

40. Chastain SR, Kundu AK, Dhar S, Calvert JW and Putnam AJ: Adhesion of mesenchymal stem cells to polymer scaffolds occurs via distinct ECM ligands and controls their osteogenic differentiation. J Biomed Mater Res A 78: 73-85, 2006.

41. Malek S, Kaplan E, Wang JF, Ke Q, Rana JS, Chen Y, Rahim BG, Li M, Huang Q, Xiao YF, et al: Successful implantation of intravenously administered stem cells correlates with severity of inflammation in murine myocarditis. Pflugers Arch 452: 268-275, 2006.

42. French KM, Maxwell JT, Bhutani S, Ghosh-Choudhary S, Fierro MJ, Johnson TD, Christman KL, Taylor WR and Davis ME: Fibronectin and cyclic strain improve cardiac progenitor cell regenerative potential in vitro. Stem Cells Int 2016: 8364382, 2016.

43. Shi S, Wu X, Wang X, Hao W, Miao H, Zhen L and Nie S: Differentiation of bone marrow mesenchymal stem cells to cardiomyocyte-like cells is regulated by the combined low dose treatment of transforming growth factor- $\beta 1$ and 5-azacytidine. Stem Cells Int 2016: 3816256, 2016.

44. Kado M, Lee JK, Hidaka K, Miwa K, Murohara T, Kasai K, Saga S, Morisaki T, Ueda Y and Kodama I: Paracrine factors of vascular endothelial cells facilitate cardiomyocyte differentiation of mouse embryonic stem cells. Biochem Biophys Res Commun 377: 413-418, 2008

45. Gassanov N, Devost D, Danalache B, Noiseux N, Jankowski M, Zingg $\mathrm{HH}$ and Gutkowska J: Functional activity of the carboxyl-terminally extended oxytocin precursor Peptide during cardiac differentiation of embryonic stem cells. Stem Cells 26: 45-54, 2008.

46. Kasahara H, Bartunkova S, Schinke M, Tanaka M and Izumo S: Cardiac and extracardiac expression of Csx/ Nkx2.5 homeodomain protein. Circ Res 82: 936-946, 1998. 
47. Xu C, Police S, Rao N and Carpenter MK: Characterization and enrichment of cardiomyocytes derived from human embryonic stem cells. Circ Res 91: 501-508, 2002.

48. Gaustad KG, Boquest AC, Anderson BE, Gerdes AM and Collas P: Differentiation of human adipose tissue stem cells using extracts of rat cardiomyocytes. Biochem Biophys Res Commun 314: 420-427, 2004.

49. Bloor DJ, Wilson Y, Kibschull M, Traub O, Leese HJ, WinterhagerE and Kimber SJ: Expression of connexins in human preimplantation embryos in vitro. Reprod Biol Endocrinol 2: 25, 2004.

50. Souders CA, Bowers SL and Baudino TA: Cardiac fibroblast: The renaissance cell. Circ Res 105: 1164-1176, 2009.
51. Szaraz P, Librach M, Maghen L, Iqbal F, Barretto TA, Kenigsberg S, Gauthier-Fisher A and Librach CL: In vitro differentiation of first trimester human umbilical cord perivascular cells into contracting cardiomyocyte-like cells. Stem Cells Int 2016: 7513252, 2016.

52. Schulz R and Heusch G: Connexin 43 and ischemic preconditioning. Cardiovasc Res 62: 335-344, 2004.

53. Thomas SA, Schuessler RB, Berul CI, Beardslee MA, Beyer EC, Mendelsohn ME and Saffitz JE: Disparate effects of deficient expression of connexin43 on atrial and ventricular conduction: Evidence for chamber-specific molecular determinants of conduction. Circulation 97: 686-691, 1998. 